\title{
Politics, Policy and History: History Teaching in Irish Secondary Schools 1922-1970
}

John O'Callaghan

\section{(2) OpenEdition \\ 1 Journals}

\section{Electronic version}

URL: http://journals.openedition.org/etudesirlandaises/2119

DOI: 10.4000/etudesirlandaises.2119

ISSN: 2259-8863

\section{Publisher}

Presses universitaires de Caen

\section{Printed version}

Date of publication: 30 June 2011

Number of pages: $25-41$

ISBN: 978-2-7535-1348-8

ISSN: 0183-973X

\section{Electronic reference}

John O'Callaghan, « Politics, Policy and History: History Teaching in Irish Secondary Schools

1922-1970 ", Études irlandaises [Online], 36-1 | 2011, Online since 30 June 2013, connection on 14 November 2019. URL : http://journals.openedition.org/etudesirlandaises/2119

This text was automatically generated on 14 November 2019 .

(c) Presses universitaires de Rennes 


\section{Politics, Policy and History: History Teaching in Irish Secondary Schools 1922-1970}

John O'Callaghan

1 In the Ireland of 1922 history was very much a slave of politics. The events of the immediate past, including the partitioning of the country, meant that the course of Irish history was a matter of current affairs. The government of the Irish Free State had a vested interest in disseminating its own version of history. This article examines the role of history teaching in Irish secondary schools in the period 1922-70. It assesses what objectives were the most important in history teaching and what interests school history was designed to serve. The emphasis is on the political, cultural, social and economic factors that determined the content of history textbooks, the history curriculum and its development. The primary focus is on the politics and policy of history teaching, including the respective contributions of church and state to the formulation of the history programmes. It is argued that a particular view of Ireland's past as a Gaelic, Catholic-nationalist one informed the ideas of policy makers and thus provided the basis of state education policy, and history teaching specifically. The conclusion drawn is that history teaching was used by elite interest groups, namely the State and the church, in the service of their own interests. It was used to justify the State's existence and employed as an instrument of religious education. History was exploited in the pursuit of the objectives of the cultural revival movement, being used to legitimise the restoration of Irish as a spoken language.

\section{Policy}

2 The administration of education in the south of Ireland became the responsibility of the Provisional Government of the Free State on 1 February 1922. The Dáil Commission on Secondary Education sat from 24 September 1921 to 7 December 1922 when it presented its recommendations to the Free State minister for education, Eoin MacNeill. Its purpose, 
according to Frank Fahy of the Ministry for Education, was to determine how best education could be used to aid the revival of "the ancient life of Ireland as a Gaelic state, Gaelic in language, and Gaelic and Christian in its ideals" ${ }^{1 "}$. The report of the Commission recommended that Irish, history and geography should constitute the Gaelic core of the curriculum $^{2}$. The proposal to place Irish at the centre of the curriculum was a radical departure from the system in operation under the old Intermediate Education Board that operated under British rule. Equally radical was the proposal that geography and history should be compulsory and have an Irish orientation.

Patrick Pearse was the foremost pre-independence pioneer of Irish-Ireland education. Pearse fits Seán Farren's profile of the ideologue of indigenous culture as an alternative to that disseminated by the colonial power ${ }^{3}$. Pearse looked forward to the post-colonial phase when national identity would be fully restored. He argued that all of Ireland's problems originated in the education system. It was "the most grotesque and horrible of the English inventions for the debasement of Ireland ${ }^{4}$ ". Pearse believed that the national consciousness was enshrined mainly in the national language ${ }^{5}$. Before he converted to political rather than strictly cultural nationalism, Pearse's primary objective was the preservation of the Irish language:

when Ireland's language is established, her own distinctive culture is assured [...] all phases of a nation's life will most assuredly adjust themselves on national lines as best suited to the national character once that national character is safeguarded by its strongest bulwark ${ }^{6}$.

By 1912, when he wrote "The Murder Machine", Pearse had taken up the sword as well as the pen. It encapsulated his main educational ideas and introduced a new political dimension. He asserted that the education system was a vehicle of cultural imperialism. It contained no national material. As a result, Irish people were enslaved, and because the machine was so effective, they were not conscious of their cultural slavery ${ }^{7}$. Pearse believed that Ireland needed political independence and the restoration of promotion of knowledge of the national past in the schools in order to counter the effects of mental and cultural colonisation. Ideas similar to those of Pearse were invoked in the formation of education policy in independent Ireland. Michael Tierney, professor of Greek, and subsequently president of University College, Dublin (UCD), also outlined his philosophy on schooling with a view to an independent Ireland. Like Pearse, he considered the British system of education as "grotesque ${ }^{8}$ ". He agreed that it was designed to destroy separate Irish nationality and to make children disregard that they were Irish'. Tierney believed that the very purpose of a free Irish State would be to forge an Ireland through education that linked the Gaelic State of the past to what he envisaged as the Christian State of the future ${ }^{10}$. The basis of all teaching would be the Irish language, history, music and art. As with Pearse (and his father-in-law Eoin MacNeill), Tierney believed the history and language of Ireland were closely connected ${ }^{11}$.

Eoin MacNeill, the first secretary of the Gaelic League and professor of ancient Irish History at UCD, was the minister for Education from August 1922 to November 1925. This was a decisive period in the determination of the direction of the new Irish education system. MacNeill declared that for the members of the government to abandon the attempt to revive Irish would be to abandon their own nation ${ }^{12}$. He regarded the language as the distinctive lifeline and the principal thread of Irish nationality ${ }^{13}$. The essential element in MacNeill's Irish-Ireland was the language. He believed that ignorance of Irish history was the chief cause of want of interest in the Irish language. He felt that to anyone 
who did not identify himself with Irish history, the learning of the language would be a mere philology ${ }^{14}$. In his academic work, MacNeill identified the basis of the Irish nation in the remote Gaelic past. He showed that the Irish nation was an ancient historical entity whose formation could be traced back to the fifth century: "the Irish people stand singular and eminent...from the fifth century forward, as the possessors of an intense national consciousness ${ }^{15}$ ". He outlined the continuity of Irish history from pre-Celtic to contemporary times and found the origin of Irish laws and institutions in the remote past ${ }^{16}$. In this way, he connected ancient Ireland with modern Ireland as one constant and timeless nation, establishing the ancient historical roots of the new state. MacNeill stated that "the business and main functions of the Department of Education in this country are to conserve and build up our nationality ${ }^{17}$ ". Thus, MacNeill epitomised both the Gaelic ethos and the historical perspective of the founding fathers of the nascent state. MacNeill, as a devout Catholic, also epitomised the religious standpoint of Free State political leaders. MacNeill's successors in the education portfolio, John Marcus O'Sullivan, Thomas Derrig and Richard Mulcahy, held attitudes on the relative roles of church and state in education, the promotion of the language revival and the ideal of a Gaelic Ireland that were indistinguishable from his.

6 The first annual report of the Department of Education highlighted the fact that the central educational aim of the Free State was "the strengthening of the national fibre by giving the language, music, history and tradition of Ireland their natural place in the life of Irish schools ${ }^{18}$. In the spirit of the recommendations of the Dáil Commission, the new history syllabi betrayed radical changes in approach and attitude. At both junior and senior levels, there was a far greater emphasis on Irish history ${ }^{19}$. Under the Intermediate Board, British and Imperial history had been promoted at the expense of Irish history but the opposite became the case. The inclusion of a full outline course of Irish history in its own right, combined with the exclusion of British and Imperial history, was in line with the State policy of using education, and history within it, to create an "Irish Ireland". The neglect of Irish history under the Intermediate Board had been interpreted as a deliberate policy of anglicisation, and the cultivation of Irish history was designed to serve the process of gaelicisation ${ }^{20}$. In 1925, Joseph O'Neill, secretary of the Department of Education, wrote to W. T. Cosgrave that education policy aimed "to redress the balance and to make compensation" for the neglect of Irish culture under the previous system ${ }^{21}$. This echoed Pearse's thinking. In 1931, the Department of Education argued that until the history of Ireland was properly taught the work of gaelicisation would be hindered, since there would be "no real incentive to urge the pupils to the use of Irish as a living speech ${ }^{22}$ ". This echoed MacNeill's thinking. The extent of the change in emphasis from British to Irish history was made clear by the reports of examiners and inspectors, who commented on the ignorance of British history displayed by many students in matters in which Ireland was directly affected by Britain:

It is undesirable that teachers should treat Irish history as an isolated phenomenon or should fail to explain the connection between events in Ireland and the contemporaneous events in Great Britain and Europe ${ }^{23}$.

7 The tendency, apparent in the syllabi, to study the history of Ireland in isolation was still an issue in the 1970s, even as the project of European unity gathered pace and Ireland joined the EEC in 1973. Policy makers intended history to reflect a romantic but unhistorical ideal of Ireland's Gaelic past held by many Irish revolutionaries. Pearse, for example, idealised education in pagan and early Christian Ireland and argued that its character could be revived through an education of "adequate inspiration ${ }^{24 "}$. He believed 
that "a heroic tale is more essentially a factor in education than a proposition in Euclid [... ] What Ireland wants beyond all [...] is a new birth of the heroic spirit ${ }^{25 "}$. However, the conception of history and history teaching as a method of restoring and renewing the Gaelic past did not consider those whose past was not a Gaelic one. The emergence of a new consensus on Irish identity meant that those who did not subscribe to it, in political, cultural or historical terms, became outsiders in the State. For many unionists, nationalism and the cultural revival were inextricably linked with Catholicism. The Catholic Church was suspected of nurturing an extreme nationalism in its schools. Echoing Canon Law, the Central Association of Catholic Clerical School Managers had asserted in 1921 that

We are confident that an Irish government... will always recognise and respect the principles which must regulate and govern Catholic education [...] The only satisfactory system of education for Catholics is one wherein Catholic children are taught in Catholic schools by Catholic teachers under Catholic control ${ }^{26}$.

In 1924, the orthodox Catholic Bulletin declared that "the Irish nation is the Gaelic nation; its language and literature is the Gaelic language; its history is the history of the Gael. All other elements have no place ${ }^{27}[. .$.$] " When the State of Northern Ireland was set up, the$ main Protestant churches transferred their ownership of schools to the State. Irish history was dropped entirely from the curriculum of State schools ${ }^{28}$. The Catholic Church retained ownership of its schools. In the south, the Catholic Church played a dominant role in the management of education. The distinctions were less explicit than in the north but the dynamics of the system raised issues about denominational, non-denominational and secular perspectives on education. The majority of schools were de facto Catholic schools. The Catholic Church claimed the allegiance of 95 per cent of the Free State population. With the exception of Ernest Blythe, the first Free State cabinet consisted entirely of Catholics $^{29}$. In contrast with southern Catholic nationalists, southern Protestant unionists felt deeply the pressure of political change. Many schools under Protestant management did not subscribe to the Gaelicising policies and the historical perspective of the new state. They had to bear the rigours of a state Gaelicisation policy, or else see their schools deprived of all public funding. Letters sent to the Taoiseach in 1944 by the Presbyteries of Monaghan, Letterkenny and Raphoe illustrate the attitude of Protestant schools to the use of Irish as a teaching medium ${ }^{30}$. The Presbyteries acknowledged the cultural value of Irish as a subject of study but argued that it was granted an undue proportion of the timetable and that the policy of using it as the chief medium of instruction was not educationally beneficial for children whose home language was English. The letters also recorded anxieties that the setting of exam papers for entry to teacher training colleges in Irish only would seriously imperil the supply of Presbyterian teachers ${ }^{31}$.

9 The significance given to school history teaching by the new government was revealed in 1922 when it became a compulsory subject in primary schools. The programme followed from 1925 dealt exclusively with Irish history and changed little until the introduction of the new curriculum for primary schools in 1971. In 1934, the Department of Education outlined the approach that it wanted primary school teachers to take to history:

In an Irish school in which history is properly taught, the pupils will learn that they are citizens of no mean country, that they belong to a race that has a noble tradition of heroism and persistent loyalty to ideals. In such a school no formal exhortation should be necessary to bring home to every pupil the worth of good faith, courage and endurance, and the strong grounds that they are for a belief that 
a race that has survived a millennium of grievous struggle and persecution must possess qualities that are a guarantee of a great future [...] Irish history has been much distorted by those who wrote from the enemy's standpoint. Such writers had to attempt to justify conquest and expropriation ${ }^{32}$.

10 The policy of Gaelicisation, then, was aimed mainly at the primary schools and only to a limited degree at secondary schools. This emphasis on the primary school was due to the realisation that it was more effective to begin orientation at the earliest suitable age, and to the fact that secondary schools were almost exclusively in private denominational hands. It was also the case that a relatively small proportion of students continued their education beyond primary school level. In addition to these factors, secondary schools were much more independent of the Department of Education than were primary schools. Supervision of primary schools by a vast inspectorate was much more intense than was the case at secondary level. For a complete understanding of the philosophy underlying the new history programmes and of the role of history in secondary schools during the early years of the new history programme, an understanding of the influence of Rev. T. J. Corcoran, S. J., professor of Education at UCD between 1909 and 1942, is necessary. Joseph O'Neill, secretary of the Department of Education from its foundation until 1944, regarded him highly: "In the reconstruction of the Irish State he was from the beginning the master-builder in education ${ }^{33}$ ". Corcoran championed a traditional Catholic view of education. He did not accept that history should be a subject of secular instruction. He declared that the history curriculum was aimed at reversing British modes of historical study, which were "inimical to the study of the work and development of the Church of Christ ${ }^{34 "}$. He argued for the teaching of history in the new secondary school curriculum to reflect a Catholic spirit and outlook ${ }^{35}$. He urged all Catholic schools to provide a course in history wherein the Church would occupy its rightful place as the driving force in all civilisations and progress ${ }^{36}$. Corcoran explicitly viewed history as a branch of Catholic religious, moral and sociological training. He believed the critical utility of history in secondary school was to produce "the class with the Catholic mind, whose members will later on not be inclined to shirk the use of moral decisions on the facts of public life" and to "produce the citizen who will not fear to be explicitly Catholic in the field of social action ${ }^{37 "}$. Corcoran was particularly influential in the formation of educational policy in the early years of the Irish Free State. He dominated the proceedings of the Dáil Commission on Secondary Education and he took a central role in determining the new programmes for primary and secondary schools ${ }^{38}$.

11 The 1960 report of the Council of Education identified the dominant purpose of secondary schools as the inculcation of religious ideals and values ${ }^{39}$. The aim of the schools was "to prepare their pupils to be God-fearing" so that they could responsibly discharge their duties to $\operatorname{God}^{40}$. The prevailing curriculum was "the grammar school type, synonymous with general and humanist education ${ }^{41}$ ". The report endorsed that role in concurrence with an informal system of vocational guidance ${ }^{42}$. It acknowledged the primacy of the humanist subjects and stated that the chief aim of school history was not the training of scientific historians or the critical spirit, except in a broad way, but the development of the civic and moral sense ${ }^{43}$. It confirmed the curriculum as still on the lines of that adopted in 1924 following the recommendation of the Dáil Commission on Secondary Education. It accepted the status quo and affirmed that little change had taken place. There had been developments and variations, but the Council acknowledged that there had been no departure from the fundamental principles adopted in $1924^{44}$. The Council's endorsement of the existing curriculum suggested an apparent lack of awareness 
regarding the more analytical and dynamic thinking afoot which would transform secondary education during the following decade. By the time the report was finally published in 1962, the pace of change in Irish society had outstripped it, making the Council seem outmoded and its limited proposals redundant. Reaction to the report was negative ${ }^{45}$. The Irish Independent of 26 April 1962 argued that the Council was not in tune with the spirit of reform evident in the air at teachers' conferences: "The most outstanding feature of the Council's report is that it sees no need for any really farreaching changes". The Irish Times of the same date reported that the Council did not make any firm decision on any potentially controversial issue, including the teaching of recent Irish history: "The report of the Council of Education has missed a singular opportunity to give a new direction to the cultural and commercial orientation of Irish secondary education". During most of the period from independence to the 1960s, one of the most remarkable features of Irish education policy was the reluctance of the state to encroach on the entrenched position of the Catholic Church. The claims of the Catholic Church were not moderate however: it actually established for itself a more extensive control over education in Ireland than in any other country in the world. Political leaders never publicly questioned the prerogatives that the Church established for itself in education. They were mainly the products of Catholic schools, were staunchly Catholic and obeyed the rulings of the church on moral issues. Due to Church-State cooperation on education and the influence of Corcoran, the role of history in secondary schools was largely in accordance, and certainly not incompatible with, a Catholic world-view. Changes that came about in education in the 1960s entailed a sudden increase of state intervention in a field where the Catholic Church had long been dominant. In 1963, the Minister for Education, Dr. Patrick Hillery, announced in the Dáil, as he had done in the public press, that matters of educational policy would be formulated on the sole responsibility of the minister concerned, with, if necessary, government approval, and that policy matters would not be submitted to outside bodies prior to their promulgation ${ }^{46}$.

12 Education was a moribund department until the 1960s. Compared with previous decades, a feature of the 1960 s was a significant increase in government interest in education. The context was the programme of economic reform initiated by the Fianna Fáil government under Seán Lemass. The aim of the reform programme was to prepare Irish industry, commerce and agriculture to meet the economic demands of the EEC. Reform was also influenced by Ireland's increasingly strong links with international organisations such as the Council of Europe and the United Nations. Irish economic policy was moving from protectionism to free international trade. In 1962, the Minister for Education, George Colley, in conjunction with the Organisation for Economic Co-operation and Development (OECD), established a panel to review Irish educational institutions and goals. In contrast with the Council of Education, its members were not educationists but leading civil servants, academics and economists. Its broad terms of reference indicated an intention to frame the development of education within the wider economic development of the State ${ }^{47}$. The 1965 report, Investment in Education, promoted the planned development of education as a contribution to economic growth. Colley told the OECD that

For us in Ireland this report has had an immediate impact on policy. We are now embarked on the long and arduous task of adapting our educational system and institutions to serve the needs of the nation in the age of technology and, we hope, rapid economic growth ${ }^{48}$. 
13 education was pushed away from its former insularity by policy makers and became more outward looking, as well as becoming more inclusive of internal Irish interests. The inclusion of such topics as "Life in Presbyterian Ulster", "The Birth of Orangeism" and "The End of the Catholic-Dissenter Alliance" was set in the context of improving relations between the Republic and Northern Ireland, symbolised by meetings between Lemass and Terence O'Neill, the Northern Prime Minister, in 1965. It seemed to indicate a move away from traditional narrow Catholic-Gaelic nationalism. Many curricular changes were introduced into secondary schools in an attempt to satisfy the needs of an increasingly industrialised economy. History became less important as the sciences became more important. The decline in the proportion of pupils taking history may be gauged from the fact that, in 1960, 70 percent of boys and 74 percent of girls took history; by 1970 the figure for boys had dropped to 42 percent and for girls to 44 percent.

\section{Textbooks}

Evidence that teachers often failed to discuss the material presented in textbooks means that their content was of vital importance. In many schools history suffered from the fact that the teachers were not specialists, and limited the scope of the course to the contents of meagre texts in which the information was often incorrect and out-of-date ${ }^{49}$. Department of Education reports continually referred to excessive dependence on the textbooks and to memorisation of the textbooks: "There is too much adherence to the matter in arid little textbooks, and teachers still are found who substitute the lifeless reading aloud of such books for real oral exposition ${ }^{50}$ ". Following school visits, inspectors reported that many teachers had no historical knowledge beyond what they found in elementary textbooks ${ }^{51}$. If the only history that many teachers knew was what they had picked up from the same texts that their pupils used, it is understandable that the opinions of the authors of these books could assume significant authority. In situations where the textbook was dominant, the only alternative sources of historical knowledge for children would have been outside the school. There is evidence that the books carried a spirit of ethnocentric nationalism and Anglophobia. John Marcus O'Sullivan urged teachers to use textbooks to present an Irish perspective on events but warned of the dangers of "cultivated chauvinism" ${ }^{52}$ ". However, in 1943 a history teacher in Newtown school in Waterford condemned textbooks for being biased in outlook and overemphasising the persecution theme:

in Irish history as it is written today every villain is a foreigner and every hero is an Irishman, and if there was such a thing as an Irish villain, his existence must be hushed up, for the ancient Gaels lived in the Golden Age ${ }^{53}$.

The textbooks of the Christian Brothers were explicitly nationalistic. The twentieth century publications of the Christian Brothers legitimised physical force republicanism by celebrating the acts of Emmet and Pearse. The Senior Reader (1932) told pupils that that the "national ideal" must be "shielded by every power and faculty... even unto death". The banner of freedom was the hallmark of every Irish insurrection: "It was the flag of Davis, Tone and Pearse and it is the flag that Ireland will always stand by, if its nationality is to be vindicated ${ }^{54}$." It has been suggested however, that the influence of the Christian Brothers' textbooks should not be overemphasised because they were "only part of a much wider diffusion of nationalist ideas" and because "the link between the content of a 
history textbook and practical action, which by definition nationalism is, is a tenuous one 55". The precise influence of Brothers' books is impossible to quantify but should be seen in the context of the nationalist tone and ethos of Brothers' schools.

While schools were criticised for using nationalistic texts, complaints that the books were not nationalistic enough, were weak on fundamental political and religious issues, and were too sensitive to British sentiments were not uncommon. In 1923, Corcoran condemned "our Anglicised manuals of Irish history", which he believed wilfully and repeatedly disparaged Irish achievements ${ }^{56}$. Thirty years later, Senator Frederick Summerfield argued that the benefits of Gaelicisation were still being counteracted by the "compulsory imperialism" of textbooks, "identical in every respect with the standardised English secondary school reader", that taught schoolchildren that Ireland's national heroes were those of another country ${ }^{57}$. Protestants also took issue with some of the textbooks used in schools, though for different reasons. In 1929, the General Synod of the Church of Ireland requested stricter Departmental regulation of national school textbooks on the grounds that several, particularly books in Irish, included religiously offensive content. Such books were also in use in secondary schools but little was done about the issue ${ }^{58}$. Henry Kingsmill Moore, president of the Church of Ireland teachertraining college at Kildare Place, wrote a number of elementary histories of Ireland from a unionist perspective. MacShamhráin assessed these books as a "largely successful attempt to provide an alternative and non-contentious account of the major issues of religious controversy ${ }^{59}$.

The textbooks of Alice Stopford Green (1847-1929) and P. W. Joyce (1827-1914) were widely used in the schools. Roy Foster described Alice Stopford Green as a "zealot" and a "formidable and virulently partisan advocate of Irish nationalism"6". R. B. McDowell considered her books to have "provided formidable propaganda for the nationalist cause ${ }^{61}$ ". The inclusion of two of her works, The Making of Ireland and its Undoing 1200-1600 and Irish Nationality, on the list of books recommended for teachers by the Department of Education in 1934 indicates that her work was held in high esteem ${ }^{62}$. The dominance of the nationalist ideology that prevailed in the years following independence can be partly attributed to Stopford Green because her emphasis on the cultural distinctiveness of the Gaelic race and her portrayal of a Tara-based national sovereignty served to provide a historical rationale for independence and unity. She introduced The Making of Ireland by explaining how

The invading people effaced the monuments of a society they had determined to extirpate, and so effectively extinguished the memory of that civilisation [...] There is no more pious duty to all of Irish birth than to help in recovering from centuries of obloquy the memory of noble men [...] who built up the civilisation that once adorned their country [...] It is in the study of their history alone that Irishmen will find this just pride restored, and their courage assured ${ }^{63}$.

Her work centred on the proposition that the memory of Ireland's former Gaelic civilisation was deliberately blotted out by the English as though it had never existed. Instead they painted a picture murky and savage and stained with every vice and folly. The growth of this myth through seven centuries was for Stopford Green the most stupendous fact of Irish history ${ }^{64}$. She dismantled this myth and substituted her own nationalist allegory. She echoed this theme in Irish nationality when she depicted the objective of the English as the destruction and wiping out of the whole Gaelic tradition and all memory of it, with the intent of establishing a new English order ${ }^{65}$. The slaughter of poets and historians and the burning of their books and genealogies would accomplish 
this ${ }^{66}$. However, the Irish showed supreme and unselfish loyalty to their race by continuing to cherish their language, poetry, history and law with the old pride and devotion. Out of the depths of their suffering, they left to succeeding generations one of the noblest examples in history ${ }^{67}$. In her disdain for the British presence in Ireland, and her belief that the country could only prosper when that link was severed, Stopford Green, daughter of an archdeacon and wife of the historian, Rev. J. R. Green, did not subscribe to the conventional Protestant viewpoint. Her work conformed and contributed to popular belief to the extent that it "entered the mainstream of Free State culture ${ }^{68}$ ". Her books embodied the Gaelic if not the Catholic-nationalist view of history.

P. W. Joyce, a professor and president of Marlborough Street teacher training college, was among the most prolific authors of school textbooks. He aimed to write soberly and moderately, avoiding exaggeration and bitterness and treating all objectively while sympathising heartily with Ireland and her people ${ }^{69}$. He concentrated on the valour and romance of the native character ${ }^{70}$. His work has been characterised as attempt to steer a course between nationalist and unionist poles ${ }^{71}$. A comparison of Joyce's treatment of 1798 with Stopford Green's reveals a salient imbalance in their approaches. Both accept that the people of Wexford were driven to rebellion by the actions of the British military forces. However, while Joyce acknowledged that they committed terrible excesses against Protestants in retaliation, Stopford Green failed to make any mention of the massacres ${ }^{72}$. This omission is symptomatic of the suppression and denial of episodes that did not fit in with the popular nationalist history, in which all the Irish were heroes and all the British were villains. It was not until 1966 that Department inspectors met with publishers to outline the type of textbooks they wanted. Fundamental changes in design reflected an equally radical approach in the text. Widespread use was made of volumes produced in the south in northern schools which in the past neglected the history of Ireland and treated books from the south with a great deal of suspicion. It has been suggested that the new books displayed no evidence of religious or political prejudice ${ }^{73}$.

The issue of the use and abuse of textbooks has been one of the central controversies surrounding Irish history teaching. A consensus has emerged among scholars that the views expressed in textbooks tended to reflect rather than form public opinion ${ }^{74}$. This interpretation mirrors the relationship between history teaching and national identity and serves to further distinguish school history teaching from professional academic history, which aspired to differentiate between historical truth and popular received myth. The content of Irish history textbooks proved highly problematic. The challenge of producing textbooks that catered for all loyalties was not of course unique to Ireland. Doherty argued that what made the Irish predicament so acute was the difficulty of reconciling the dichotomies of the good Irishman and the evil Englishman, the poor tenant and the cruel landlord because these dichotomies reflected widespread Irish prejudices $^{75}$. The above examples show that not all authors accepted the challenge of reconciling these dichotomies. That criticisms of textbooks first made by inspectors in the 1920s were not acted on by the Department until forty years later may indicate that the Department was satisfied to maintain the status quo in relation to what Seán ó Faolain called its "fairytale" textbooks ${ }^{76}$.

21 The fundamental role that history can play in the development of patriotic attitudes was recognised and exploited in the Irish Free State. History was used in the pursuit of extraeducational objectives. The political objective was the most important in history teaching, and, as such, history teaching operated as a political instrument. Its end, in so 
far as it concerned the State, was chiefly political; the production of loyal citizens and the justification and preservation of the State's existence. As a part of the school curriculum, the subject of history taught young learners a monolithic nationalist, anti-British and pro-Catholic history that was heavily dependent upon allegory and collective memory. School history was a major part in a State project to preserve and propagate what it meant to be Irish. It was based on the twin aims of developing a State that was Gaelic and predominantly Catholic in outlook and spirit. The primary objective of history teaching was the transmission of the distinct nationality upon which the State was founded. "The past" served the multitude as well as the elite: it allowed the Irish people to reconcile themselves to contemporary economic and social woes while taking pride in the selfimage it offered them of a people with an inner spirituality; it distinguished the Irish from the English in terms of race and culture, thus demonstrating the existence of an Irish nation and validating the existence of the State. As a critical part of the policy of gaelicisation, history teaching took on an emphatically patriotic tone and sought to validate the nationalist cause in a teleological manner that lacked historical perspective. The function of history was to convince students of the unique qualities of the Gaelic nation and imbue them with that same Gaelic spirit which had endured centuries of oppression under the British before coming into its inheritance of independence. Students heard the story of Ireland from the halcyon days of the pre-Norman era, through a long struggle of conquest, persecution, endurance and deliverance. The narrative featured martyrs like Wolfe Tone, Emmet, O'Donovan Rossa, Connolly and Pearse. The young people of Ireland were taught how a glorious past culminated in and justified the new State. The purpose of history was to help to transform Ireland back into the Gaelic State that it once was.

The chief function of Irish educational policy was to conserve and develop Irish nationality. Thus, the schools of the Irish Free State were charged with the task of building Irish nationality. They were the chief mechanism in a continuing cultural revolution. The idea of a Gaelic Ireland was synonymous with independent Ireland. The Irish language was central to Irish national identity. The primary function of the schools was to recreate a Gaelic, Irish-speaking nation. The education system aimed to develop awareness and appreciation of what made the Irish a unique and great race. This distinctive and peerless heritage was the foundation for independence. The function of history was to play a supporting role to Irish by strengthening the national fibre and illustrating the distinctiveness and continuity of the Irish nation. History was used to demonstrate the importance of the Irish language in preserving national consciousness and continuity, and thus legitimise its restoration as a spoken language.

The nationalist role ascribed to history in primary schools was not as pronounced in secondary schools. This was because the type of indoctrination involved was more effective with younger subjects, and relatively few students went on to secondary level. Perhaps the most important factor that determined the function of history at secondary level was the Catholic philosophy that permeated secondary education. The study of history was not a secular pursuit but a branch of religious education and an instruction in proper Catholic living. As a part of the school curriculum, the subject of history taught young learners a monolithic nationalist, anti-British and pro-Catholic history that was heavily dependent upon allegory and collective memory. School history was a major part in a State project to preserve and propagate what it meant to be Irish. While there were some discrepancies between what Pearse envisaged for post-colonial Ireland and the 
structure that was actually put in place, the education system of Free State Ireland was, in large part, the one that Pearse had advocated. If the British "murder machine" had been responsible for the manufacturing of cultural slaves, the same charge of ideological indoctrination might be levelled at the new regime.

The new Free State was a post-colonial State. The development of a distinctly Irish identity based on the nation's Gaelic heritage, a heritage that was not recognised under the British school system, was an understandable objective because of geographical proximity to England and a history of political and cultural animosity. Leaving aside the extent to which this objective was achieved, the country paid a heavy price in pursuing it. The influence of the Catholic Church served to sustain and reinforce divisions and antagonisms between Catholics and Protestants in the south. The attempted reGaelicisation of society served to widen existing communal divisions and further alienate the minority Protestant community. It further widened the gap between north and south. It allowed no room for compromise on the issue of national identity. If the link between views of history and political thought and action, as well as the role of the school in the process of socialisation and the creation of historical and political identity has been exaggerated, the reality was that the Protestant and unionist communities perceived history teaching as a threat to their interests. Gaelic culture was proclaimed as not only relatively, but absolutely better than others. Nationalist history was not only pro-Irish but anti-British.

In terms of the function ascribed to history, it was not until the mid 1960s that Irish education emerged from "Plato's cave". Industrial expansion combined with the prospect of entering the EEC in the near future created conditions in which the role of history was viewed less in terms of building a Gaelic state and more in terms of cognitive training and citizenship. School curricula became more closely aligned with the needs of an industrialising economy. The nationalist role assigned to history at the foundation of the State was significantly diminished. Non-Gaelic elements of the Irish nation were acknowledged as relations with Northern Ireland seemed to improve. However, Ireland was about to reap a harvest, some of the seeds of which may have been sown in the education system.

\section{NOTES}

\section{Times Education Supplement, 1 October 1921.}

2. Dáil Commission on Secondary Education, Report (unpublished, mimeographed in Library of the Department of Education).

3. See Seán Farren, "Culture and education in Ireland", Compass, Journal of the Irish Association for Curriculum Development, 5:2, 1976, p. 24-38.

4. Pádraic Pearse, "The Murder Machine", Collected works of Pádraic H. Pearse - Political Writings and Speeches, Dublin, 1924, p. 6.

5. Ibid., p. 40-1. 
6. An Claidheamh Soluis, 27 August 1904.

7. Pádraic Pearse, “The Murder Machine”, Collected Works, p. 8-9, p. 40.

8. Michael Tierney, Education in a Free Ireland, Dublin, date of publication between 1918 and 1922, p. 20.

9. Ibid., p. 29.

10. Ibid, p. 26, p. 98.

11. Ibid., p. 45.

12. Times Education Supplement, 30 October 1925.

13. An Claidheamh Soluis, 5 October 1907.

14. Ibid., 28 October 1911.

15. Eoin MacNeill, The Phases of Irish History, Dublin, 1919, p. 248.

16. Eoin MacNeill, Early Irish Laws and Institutions, Dublin, 1935.

17. Dáil Debates, vol. 13, 11 November 1925, col. 187.

18. Department of Education, Report 1923-24, Dublin, 1924, p. 22.

19. See Department of Education, Rules and programmes for secondary schools 1924-25, Dublin, 1925, p. 63-6.

20. Department of Education, Report 1923-24, p. 22.

21. National Archives of Ireland (NAI), Department of the Taoiseach (D. T.), S 7801.

22. Department of Education, Report 1930-31, Dublin, 1931, p. 21.

23. Department of Education, Report 1927-28, Dublin, 1928, p. 58.

24. P. Pearse, "The Murder Machine”, Collected Works, p. 24-25.

25. Ibid., p. 38.

26. Irish Catholic Directory, 1922, p. 577-578.

27. Catholic Bulletin, 14:4, 1924, p. 269.

28. Seán Farren, "Nationalist-Catholic reaction to educational reform in Northern Ireland 1920-30", History of Education, 15:1, 1986, p. 28.

29. See E. Brian Titley, Church, State, and the Control of Schooling in Ireland 1900-44, Dublin, McGill-Queen's University Press 1983, p. 90.

30. NAI, D. T., RA 98/44.

31. Id.

32. Department of Education, Notes for teachers: History, Dublin, 1934, p. 3.

33. Joseph O’Neill, “The educationist”, Studies, 32, 126, 1943, p. 158.

34. T. J. Corcoran, "History courses and examinations, Belfast and Dublin, 1930", The Irish Monthly, 58, 686, 1930, p. 372.

35. T. J. Corcoran, "The new Secondary Programmes in Ireland: the teaching of history”, Studies, 12, 46, 1923, p. 258.

36. T. J. Corcoran, “A highway for Catholic education”, The Irish Monthly, 57, 677, 1929, p. 570.

37. T. J. Corcoran, "Moral training through history", The Irish Monthly, 56, 666, 1928, p. 622, p. 624. 
38. See Joseph O'Connor; “The teaching of Irish" in Capuchin Annual, 1949, p. 209; O'Neill, “The educationist", Studies, p. 153-62; O'Donoghue, The Catholic Church and the Secondary School. Curriculum in Ireland, 1922-1962 (New York, Peter Lang, 1999) p. 33 and Titley, Church, State, and the Control of Schooling, p. 99.

39. Council of Education, The Curriculum of the Secondary School, Dublin, 1962, p. 80.

40. Ibid., p. 88.

41. Ibid.

42. Ibid., p. 82.

43. Ibid., p. 130.

44. Ibid., p. 68.

45. These editorials are included in the file on proposals and recommendations to the Council of Education in (N. A. I., D. T., S 15015 B/61).

46. Dáil Debates, vol. 203, 30 May 1963, col. 598.

47. See the report of the survey team appointed by the Minister for Education in 1962, Investment in Education, Dublin, 1965, p. XXIX-XXXII.

48. OECD Directorate for Scientific Affairs, Investment in Education Ireland: Report of the survey team appointed by the Irish Minister for Education, Paris, 1965, p. VI.

49. Department of Education, Report 1927-28, p. 57.

50. Department of Education, Report 1928-29 (Dublin, 1929), p. 60.

51. Department of Education, Report 1930-31, p. 21.

52. Dáil Debates, vol. 29, 11 April 1929, col. 485.

53. Eileen Webster, “History in our schools”, The Bell, vol. 7, no. 3 (1943), p. 196.

54. Lorcan Walsh, "Nationalism in the textbooks of the Christian Brothers", Irish Educational Studies, vol. 6, no. 2, 1986-1987, p. 9.

55. Ibid., p. 13.

56. Corcoran, “The New Secondary Programmes”, Studies, p. 254.

57. Seanad Debates, vol. 43, 26 November 1943, col. 147.

58. Gabriel Doherty, “The Irish history textbook 1900-60: problems and development", Oideas, vol. 42, 1994, p. 19.

59. A. S. MacSamhráin, "Ideological conflict and historical interpretation: the problem of history in Irish primary education", Irish Educational Studies, vol. 10, 1991, p. 234.

60. Roy Foster, Modern Ireland 1600-1972, London, Penguin, 1988, p. 447; idem, "History" in Transactions of the Royal Historical Society, p. 185.

61. R. B. McDowell, Alice Stopford Green: A Passionate Historian, Dublin, Allen\& Figgis, 1967, p. 82 .

62. Department of Education, Notes for Teachers, p. 27.

63. Alice Stopford Green, The Making of Ireland and its Undoing 1200-1600, London, Maunsel, 1919, p. IX-XI.

64. Ibid., p. 467-468.

65. Alice Stopford Green, Irish Nationality, London, 1911, p. 132.

66. Ibid., p. 131.

67. Ibid., p. 141. 
68. Roy Foster, "History and the Irish question", Transactions of the Royal Historical Society, vol. 33, 1983, p. 186.

69. P. W. Joyce, A Concise History of Ireland from Earliest Times to 1922, Dublin, no date, p. II.

70. See John Coolahan, “The contribution of P. W. Joyce to the Irish education system” in Oideas, vol. 34, 1989, p. 75-93.

71. MacSamhráin, “Ideological conflict”, Irish Educational Studies, p. 231.

72. Joyce, A Concise History of Ireland, p. 279; Stopford Green, Irish nationality, p. 217-218.

73. Brian Mulcahy, "The concept of Ireland as portrayed in the Intermediate Certificate history textbooks" in John Coolahan (ed.), Proceedings of the fifth annual education conference of the Educational Studies Association of Ireland (Limerick, 1980), p. 66-73.

74. See MacSamhráin, “Ideological conflict”, Irish Educational Studies, p. 229.

75. Doherty, “The Irish History Textbook”, Oideas, p. 6.

76. Seán Ó Faolain, “The plain people of Ireland”, The Bell, vol. 7, no. 1, 1943, p. 6.

\section{ABSTRACTS}

The teaching of history in Ireland has proved highly relevant to the development of Irish national identity and continues to be politically and culturally significant. Critics of the approach taken to the teaching of history in Irish secondary schools between 1922 and 1970 and of the process of curricular development might suggest that deficiencies in these areas facilitated the propagation of a prejudiced account of Irish history, and contributed to a phenomenon whereby a sense of history was replaced in popular memory with a sense of grievance. This article is an analysis of the social, political, economic and cultural factors that influenced the teaching of history, the content and tone of textbooks, and the development of the history curriculum in secondary schools in the half-century following the inauguration of the Irish Free State in 1922. It charts the evolution of the exploitative relationship between church, state, and history and assesses the costs involved.

L'enseignement de l'histoire en Irlande entretient un lien étroit avec le développement de l'identité nationale irlandaise et continue d'être significatif politiquement et culturellement. Les détracteurs de l'approche adoptée dans l'enseignement d'histoire dans les écoles secondaires irlandaises entre 1922 et 1970 et dans le processus de développement du cursus, pourraient avancer que les faiblesses dans ces approches ont facilité la propagation d'un récit préconçu de l'histoire irlandaise, et ont entraîné un glissement par lequel la perception de l'histoire dans la mémoire populaire a cédé la place à un sentiment d'injustice. Cet article comprend une analyse des aspects sociaux, politiques, économiques et culturels qui ont influencé l'enseignement d'histoire, le contenu et le ton des manuels scolaires, et le développement du cursus d'histoire dans les écoles secondaires dans le demi-siècle après l'inauguration l'État Libre d'Irlande en 1922. Il prend aussi en considération l'évolution des rapports de force entre l'Église, l'État, et l'histoire et évalue les implications de ces interactions. 
INDEX

Keywords: education, history and memory, national history - teaching, national identity, trauma Mots-clés: éducation, histoire et mémoire, histoire nationale - enseignement, identité nationale, trauma

\section{AUTHOR}

JOHN O'CALLAGHAN

University of Limerick 